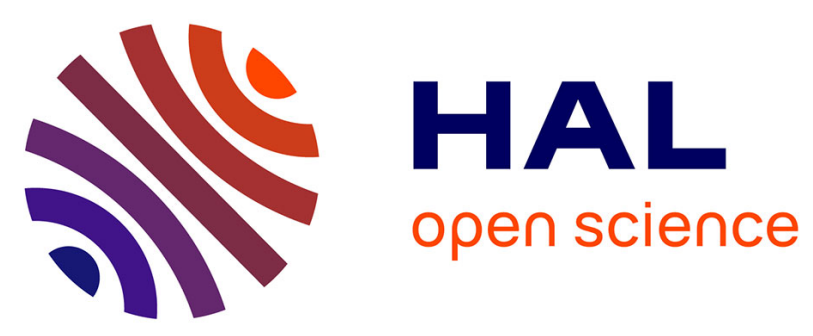

\title{
Do climate and land use affect the pool of total silicon concentration? A digital soil mapping approach of French topsoils
}

\author{
Amélia Landré, Sophie S. Cornu, J.-D Meunier, Annie Guérin, Dominique \\ Arrouays, Manon Caubet, Céline Ratié, Nicolas P A Saby
}

\section{To cite this version:}

Amélia Landré, Sophie S. Cornu, J.-D Meunier, Annie Guérin, Dominique Arrouays, et al.. Do climate and land use affect the pool of total silicon concentration? A digital soil mapping approach of French topsoils. Geoderma, 2020, 364 (Avril), pp.114175. 10.1016/j.geoderma.2020.114175 . hal-02503457

\section{HAL Id: hal-02503457 \\ https://hal.science/hal-02503457}

Submitted on 10 Mar 2020

HAL is a multi-disciplinary open access archive for the deposit and dissemination of scientific research documents, whether they are published or not. The documents may come from teaching and research institutions in France or abroad, or from public or private research centers.
L'archive ouverte pluridisciplinaire HAL, est destinée au dépôt et à la diffusion de documents scientifiques de niveau recherche, publiés ou non, émanant des établissements d'enseignement et de recherche français ou étrangers, des laboratoires publics ou privés. 


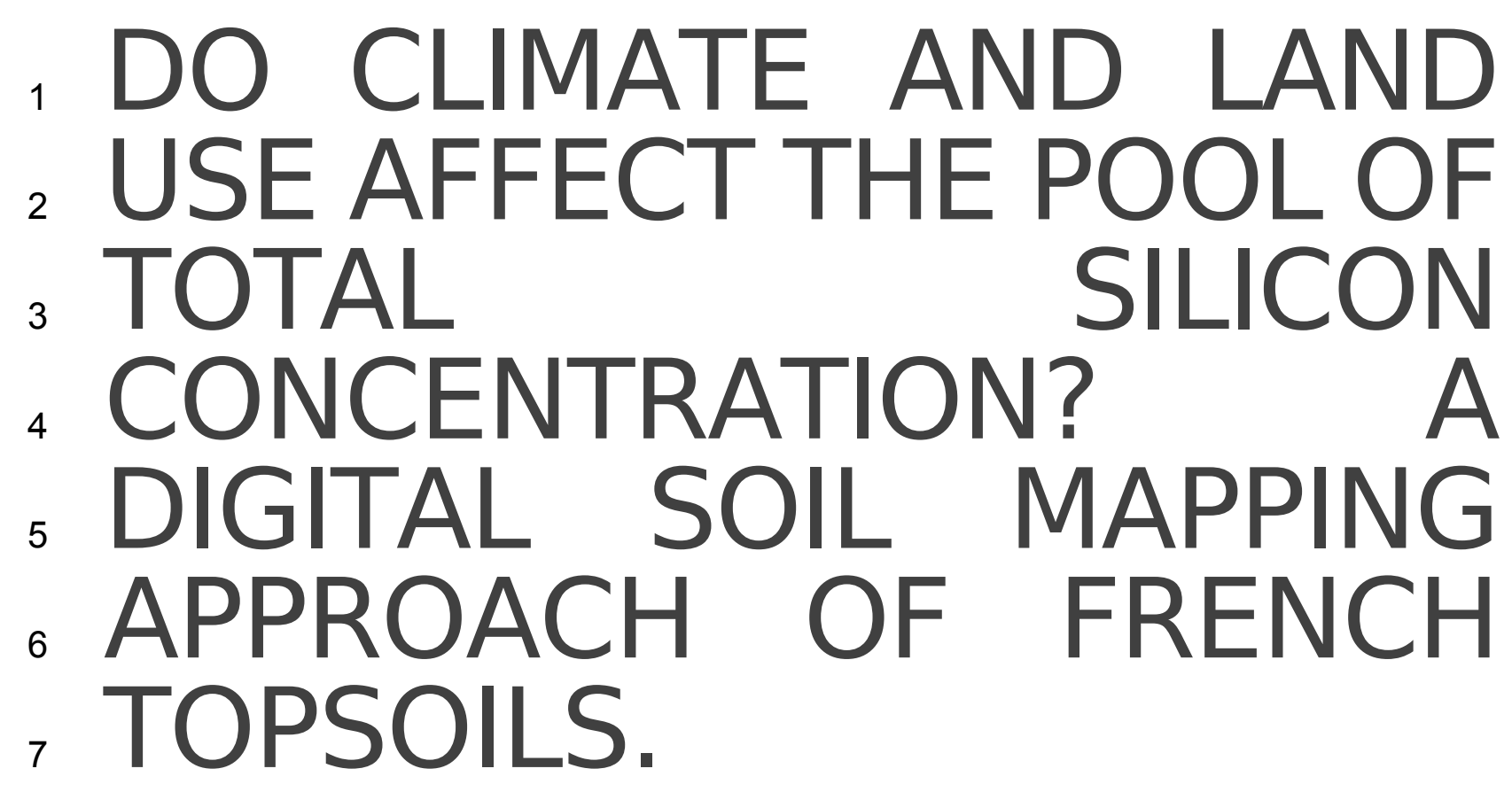

8 Landré, A. ${ }^{\mathrm{a}, \mathrm{b}}$, Cornu, S. ${ }^{\mathrm{c}}$, Meunier, J.-D. ${ }^{\mathrm{c}}$,Guerin A. ${ }^{\mathrm{d}}$, Arrouays D. ${ }^{\mathrm{a}}$, Caubet M. ${ }^{\mathrm{a}}$, Ratié C. ${ }^{\mathrm{a}}$, 9 Saby, N.P.A. ${ }^{\mathrm{a}}$

a) INRA, Infosol, US 1106, Orléans, France

b) INRA - INPT-ENSAT - INPT-EI-Purpan, UMR 1248 AGIR AGroécologie, Innovations, teRritoires. Centre de recherche Occitanie-Toulouse, Auzeville, France.

c) Aix-Marseille Univ, CNRS, IRD, Coll de France, INRA, CEREGE, Aix-en-Provence, France

d) INRA, Laboratoire d'Analyses des Sols US, Arras, France 


\section{Abstract}

18 Silicon ( $\mathrm{Si}$ ) is the second most abundant element in the Earth's crust after $\mathrm{O}$. Its 19 concentration in soils is highly variable from less than $1 \%$ to greater than $45 \%$. Parent 20 material is well known to be a major parameter for explaining this variability. In this 21 study, we proposed to analyze the impact of climate and land use on the total Si 22 concentration in soils and to explore the link between total Si and plant available Si 23 (PAS). To do so, we based our analysis on the French soil monitoring network 24 considering the upper soil horizon that was thought to be the most impacted by both 25 the effect of land use and climate and was also the most important horizon in terms of 26 plant availability. In order to extract the impact of climate and land use and for digital mapping purposes, we stratified the database by parent material and soil-types. This stratification was based on the classification used in the 1:100 000 French soil map and 1:100 000 French soil parent material map. For non carbonated soils, we showed that Si concentrations was decreasing with annual rainfall, evidencing a climatic effect on the total Si concentration of French topsoils. No significant effect of the land used could be identified. At last, we showed that PAS (by the $\mathrm{CaCl}_{2}$ method) is negatively weakly correlated to total Si concentration. This relationship is however variable among soil classes.

37 Silicon, silica, RMQS, Digital Soil Mapping, France. 


\section{Introduction}

39 Silicon is the second most abundant element in the Earth's crust after $\mathrm{O}$, and it has an average mass concentration of $28 \%$ (Wedepohl, 1995). The $\mathrm{SiO}_{4}$ tetrahedron is the elemental brick that constitutes the basic structure of Si in nature from solid (silicates) to soluble (silicic acid) states. In soils, the variability of $\mathrm{Si}$ is large, from less than $1 \mathrm{wt} \%$ in Histosols to greater than 45 wt\% in some Podzols (Sommer et al., 2006). Si is included in a large number of minerals issued either from the parent material as for instance quartz, feldspar, and phyllosilicates (muscovite, biotite for instance), or from the transformation of the parent material minerals, along weathering and pedogenesis, in clay minerals and amorphous silica particles, notably phytoliths for the part of Si recycled by vegetation (Sommer et al., 2006).

The soil concentration of total $\mathrm{Si}$ is intimately link to the concentration of Si from parent rocks (Berner and Berner, 1996; Gray et al., 2016). Gray et al. (2016 showed that sand dunes are shown to be the richest parent material (close to $100 \%$ ) while limestones are the poorest (a few percent). Among the parent material rich in Si (> $60 \%$ ), quartz and arkose sandstones, granite, rhyotite, greywacke, granolite, dacite, shale are encountered, while diorite, andesite, basalt and peridotite have Si content ranging from 40 to $60 \%$ and laterite and bauxite from 10 to $15 \%$ (Gray et al., 2016 and references included). In addition, weathering and pedogenesis modify the initial Si pool both in concentration and status (Lucas et al., 1993; White et al., 2012). The upper soil horizon is the most impacted by these processes being both depleted by weathering and clay translocation, that may have contradictory effect on the total Si concentration of the horizon. Weathering and pedogenesis are influenced by both climate and vegetation as demonstrated by river dissolved Si (DSi) (Bluth and Kump, 1994; Dürr et al., 2009) 62 at the territory scale. Using DSi in the streams as an indicator of total chemical 
63 weathering is however not straightforward because of the fraction of Si that is retained

64 in the soil for forming clay minerals or the one that is retained in biogenic silica in soils and streams (Frings et al., 2015). Analysis of climosequences have proven to be helpful for documenting some modification of the soil Si pools. On a volcanic climosequence, secondary Si phases (produced by weathering) increase under a more humid climate (Taboada et al., 2019). On intrusive rock climosequence, smectite distribution is correlated to Si loss when rainfall (or precipitation) increases (Egli et al., 2003), but the analysis of the variation of soil surface Si is not well addressed. As shown by Dere et al. (2016), the presence of poorly reactive quartz in the parent rock may be greater at the surface resulting from a relative enrichment during weathering. Therefore, the impact of rainfall on the soil Si deserves to be more fully documented.

74 While vegetation on the weathering scale is strongly correlated to climate, human activity has strongly modified the land use and thus the biological cycle of most of the elements. Some of the main cultivated crop are Si accumulators and long-term exportation may act on Si budget. It seems well documented that conversion of forest to cropland lead to a decrease of the phytolith pools (Struyf et al., 2010; Guntzer et al., 2012; Vandevenne et al. (2015). Struyf et al. (2010) suggest that the transformation of the european temperate forests into cultivated land has also lead to a decrease of

81 weathering of silicate minerals. However, Yang and Zhang (2018) came to the opposite conclusion (agricultural activities increase silicate weathering) based on a geochemical analysis of rain and streams in subtropical China. In the subtropical southern Brazil, 84 Ameijeiras-Marino et al. (2018) share Yang and Zhang (2018)'s conclusion using the Ge/Si tracer. Accordingly, the question of the intensity of the impact of land use on soil Si loss remains open. 
87 The study of the status of $\mathrm{Si}$ in soils and its biogeochemical cycle is a subject of 88 increasing interest because of the growing body of evidence showing that Si can improve crop development (Coskun et al., 2019; Guntzer et al., 2012; Liang et al., 2015; Rodrigues and Datnoff, 2015). Plant available Si (PAS) depends on the reserve of weatherable Si-bearing minerals (Cornelis and Delvaux, 2016) and can be estimated using various protocols (Narayanaswany and Prakash, 2010; Meunier et al; 2017). The relationship between soil total Si and PAS is complex depending on soil type, parent material and degree of weathering. On various agricultural soils of Asia, a negative significant correlation between PAS and soil Si content was found (Yanai et al., 2016; Meunier et al. (2017). This correlation was due to the presence of low solubility Si minerals such as quartz for explaining low PAS values. On volcanic soils containing no quartz, Henriet et al. (2008) founded a highly significant positive correlation $(n=6)$ between soil Si content and Si extracted by the $0.01 \mathrm{M} \mathrm{CaCl}_{2}$ method due to a decrease of the reserve of weathered Si minerals along weathering.

The objective of this study was to (i) determine the impact of climate and land-use on the total topsoil Si concentrations $\left(\mathrm{Si}_{\text {tot }}\right)$ in French soils and (ii) explore the relationship between $\mathrm{Si}_{\text {tot }}$ and PAS. Topsoil horizon was chosen as it was considered as the most weathered and pedogenized horizon where the roots are mainly concentrated. The French territory was chosen as (i) France is one of the countries with the largest soil diversity in the world (Minasny et al., 2010), that offers notably a good

107 representativeness of European soils notably; (ii) France processes a soil monitoring network (RMQS) for which $\mathrm{Si}_{\text {tot }}$ is available along with all the typical soil characteristics 109 (Landré et al., 2018). Indeed, soil Si is rarely analyzed at the territory scale, with the notable exception of the soil Si map at the European scale with only one site every $1112500 \mathrm{~km}^{2}$ (De Vos et al., 2006; Reimann et al., 2014) and the French soil monitoring 
112 network (RMQS) with one point at each node of 16 to $16 \mathrm{~km}$ grid (Jolivet et al., 2006;

113 Landré et al., 2018).

114 Since geology and soil type (pedologenesis) are the main Si drivers, we first stratified

115 the database in geological-pedological classes. Then we considered the impact of 116 climate and land-use in both the obtained classes and at the national scale with a 117 modern digital soil mapping (DSM) approach using the geological-pedological classes 118 defined as a covariate. The strong input of this type of covariate in the DSM model was 119 clearly demonstrated by Gray et al., (2016).

\section{Materials and Methods}

\subsection{The data}

122 Most of the data used in this study were obtained from 2111 sites from the first 123 campaign of the RMQS sampled between 2001 and 2009 (Jolivet et al., 2006), which covered all the mainland of France (around $550000 \mathrm{~km}^{2}$ ) based on a $16 \mathrm{~km} \times 16 \mathrm{~km}$ grid. Among these sites, two had no soil type description, 98 had no parent material description, six were anthroposols and three histosols. All these sites were not further considered for our analysis, ending with database of 2004 sites.

Composite samples of the top horizon $(0-30 \mathrm{~cm})$ were sampled, air dried, and sieved to $2 \mathrm{~mm}$ before laboratory analysis at the Soil Analysis Laboratory of INRA in Arras, France. The following parameters were measured: (i) the total organic $\mathrm{C}(\mathrm{OC})$ content

131 measured by dry combustion (NF ISO 10694), (ii) particle size distribution by wet 132 sieving and the pipette method (NF X 31-107), (iii) cation exchange capacity and exchangeable cations (hexamminecobalt method NF ISO 23470), (iv) pH in water (1

134 to 5 soil to water ratio; NF ISO 10390), (v) calcium carbonate using the volumetric 
method (NF ISO 10693) $\left(\mathrm{CaCO}_{3}\right)$, (vi) and total $\mathrm{P}, \mathrm{K}, \mathrm{Ca}, \mathrm{Mg}$, Fe, and $\mathrm{Al}$ determined by ICP-AES after dissolution with hydrofluoric and perchloric acids (NF X 31-147).

Landré et al. (2018) analyzed a subset of 673 samples for $\mathrm{Si}_{\mathrm{tot}}$. For the sites not analyzed, we estimated $\mathrm{Si}_{\text {tot }}$ according to the following conceptual equation:

$$
\mathrm{Si}=\mathrm{f}\left(\mathrm{Al}, \mathrm{Fe}, \mathrm{K}, \mathrm{Na}, \mathrm{Ca}_{\mathrm{nc}}, \mathrm{Mg}_{\mathrm{nc}}, \mathrm{P}, \mathrm{Mn}, \mathrm{OC}, \mathrm{CaCO}_{3} \text {, residual water }\right)
$$

where $C a_{n c}$ and $M g_{n c}$ are the fractions of $\mathrm{Ca}$ and $\mathrm{Mg}$ that are not included in carbonate minerals nor adsorbed on the exchangeable surfaces, and $\mathrm{OC}$ is the organic matter percentage. The total Si concentration in French topsoil was modelled using a Cubist modelling algorithm (see Supplementary File 1 for more details).

The database was completed by PAS measurement $\left(\mathrm{Si} \mathrm{CaCl}_{2}\right)$ using the $0.01 \mathrm{M} \mathrm{CaCl}_{2}$ method (Haysom and Chapman 1975) on 1986 sites. This widely used method (Meunier et al., 2017) allows estimating the pool of Si that is readily soluble. Briefly, $2 \mathrm{~g}$ of dry soil was mixed with $20 \mathrm{ml}$ of the solution and shaken during $16 \mathrm{~h}$ in polyethylene tubes. The solutions were then filtered at $0.45 \mu \mathrm{m}$, and $\mathrm{Si}$ concentration was measured using Inductively Coupled Plasma Atomic Emission Spectroscopy (axial ICP-AES; 720 ES, Varian).

\subsection{Stratification of the database in homogeneous geo- pedological classes}

Since $\mathrm{Si}_{\text {tot }}$ in soil is known to be linked to parent material and being anti-correlated to carbonate concentration in soils (Landré et al., 2018), we first stratified the database by the type of parent material and by the content in carbonates. In French soils, carbonates were encountered in soils developed on sedimentary rocks with a limit for carbonated soils classically considered at a $\mathrm{CaCO}_{3}$ concentration of $5 \%$ (Baize, 2000). 
158 Since a large part of the sedimentary rocks were defined on the basis of 159 geomorphological processes (e.g. alluvions, colluvions, terraces...), we were not able 160 for DSM purposes to relate directly parent material to carbonate content. In addition, 161 since we were working on the topsoil horizon, depending on the stage of pedogenesis, 162 soils developed on carbonated rocks may have been completely decarbonized (e.g. 163 Calcisols notably). Other geological domains were sorted in igneous extrusive or 164 intrusive and metamorphic. The classification used did not allow further classifying the 165 parent materials in more geochemical meaning classes as made by Gray et al. (2016), since (i) a large part of the sites had no more information than igneous extrusive or

167 intrusive or metamorphic rocks; (ii) acidic extrusive igneous rocks or basic intrusive 168 igneous rocks were too poorly represented in the database (no more than two to three 169 individuals). Podzols were also separated, these soils being mainly composed of 170 quartz were supposed to have high $\mathrm{Si}_{\text {tot }}$. We then sorted the soils in the different 171 geological groups a step further with the exception of the soils on igneous intrusive 172 rocks that were poorly represented. Soils on metamorphic parent materials and on 173 igneous extrusive rocks were sorted by soil types, ranging from poorly differentiated 174 soils (regosols, lithosols and rankers) to strongly differentiated soils (planosols, luvisols 175 and podzoluvisols) for soils on metamorphic rocks. Podzols were sorted between those 176 developed on sedimentary rock and those developed on other parent materials. For 177 non-carbonated soils on sediment, sorting was performed both by soil types and a 178 more detailed description of the considered sediment.

180 2.2.1. Mapping total topsoil Si concentrations in French soils 
181 The DSM approach was based on the work of McBratney et al. (2003), who proposed 182 a quantitative relationship between soil properties and the soil forming factors plus a 183 spatially correlated residual element (e), as follows:

$$
\text { Soil }=f(s, c, o, r, p, a, n)+e
$$

185 where Soil is a soil property. The $s$ refers to other or previously measured properties 186 of the soil at a point either from prior soil maps or from remote or proximal sensing data; $c$ refers to the climatic properties of the environment at a point; $o$ refers to organisms, including vegetation or fauna, or human activity; $r$ refers to relief; $p$ refers to the parent material or lithology; $a$ refers to the soil age; and $n$ refers to the space or 190 spatial position. Finally, $e$ is the locally varying, spatially dependent residuals from $f$.

191 We selected a set of available environmental covariates describing the scorpan factors 192 for the whole French territory. We harmonized them at $90 \mathrm{~m}$ resolution (Table 1). The 193 parental material and soil covariates were generated by the results of the PCA step. 194 We also used a very popular spectral index, namely the normalized difference 195 vegetation index (NDVI) (Huete et al., 2002). We focused on the yearly changes in the NDVI computed from a time series of remote sensing data to describe the 197 photosynthetic capacity of the vegetation cover. This variable was interpreted as a 198 vegetation growth dynamics proxy. The underlying assumption was that this 199 information on changes in vegetation may reflect various behaviors linked to climate, 200 land management or soil properties (see Loiseau et al., 2019).

201 The spatial predictive model between $\mathrm{Si}_{\text {tot }}$ and scorpan covariates was first constructed 202 using the ensemble learning method Random Forests (RF) (Breiman, 2001). We used 203 the RF implementation provided by the package randomForest in $\mathrm{R}$ (Liaw and Wiener, 
204 2002; R. Core Team, 2016). Three parameters should be defined in the RF model, 205 namely the number of trees to grow $\left(n_{\text {tree }}\right)$, the number of variables randomly sampled 206 as candidates at each split $\left(m_{t r y}\right)$, and the minimum size of the terminal nodes 207 (nodesize; Liaw et al., 2002). The default values were used for $n_{\text {tree }}$ and nodesize, 208 which were 500 and 5 , respectively. The optimal value of $m_{t r y}$ was set at 2 by the lowest 209 out-of-bag error estimate.

210 To extract useful information from this large set (22) of potentially correlated 211 covariates, we ran a preliminary step of variable selection using the Boruta algorithm 212 (Kursa and Rudnicki, 2010). This algorithm was a wrapper built around the RF 213 classification algorithm implemented in the $\mathrm{R}$ package randomForest, and it used a $\mathrm{Z}$ 214 score computed by dividing the average loss by its standard deviation. The algorithm 215 was used in feature selection (Kursa and Rudnicki, 2010), but was also applied to 216 support the model establishment of the RF regression (Kursa, 2014).

217 The residuals of the model in equation 2) were computed as the difference between 218 the RF predictions and the measured values at the observed location and then 219 interpolated by ordinary kriging (Matheron, 1971). The R package gstat (Pebesma and 220 Graeler, 2019) was used to select variogram models and perform the kriging 221 procedure. The final predictions summed the RF predictions and the Kriging outputs 222 (Keskin and Grunwald, 2018). The model performance was evaluated by 30 -folds 223 cross-validation.

224 To rank the influences of the final list of scorpan factors on $\mathrm{Si}_{\mathrm{tot}}$, we calculated covariate 225 importance from the RF algorithm as the mean increase in accuracy (\%IncMSE). This 226 indicator was constructed by permuting the values of each variable of the validation 227 set, recording the prediction error, and comparing the set with the un-permuted 
228 validation set prediction of the variable (normalized by the standard error). It calculated

229 the average increase in the squared residuals of the validation set when the variable 230 was permuted. A higher \%IncMSE value represented higher variable importance.

\section{2.2.2. Other statistical analysis}

232 Since Gray et al. (2016) showed that pedological parameters and $\mathrm{Si}_{\text {tot }}$ were highly 233 dependent from parent material composition, the database was stratified in 234 homogeneous subgroup defined on a combination of geological and pedological 235 classes, in order to use the obtained classes for DSM approach. The parent material 236 and soil type classifications used for the stratification were those used at the French 237 territory scale that is the EUSIS classification (King et al, 1994) for the parent material 238 and the FAO (1985) classification for the soil types.

239 We then performed multiple comparison tests: multiple Mann-Whitney tests, Kruskal240 Wallis tests, and a post-hoc test from Siegel and Castellan (1988). These tests were 241 performed using the medians of $\mathrm{Si}_{\text {tot }}$ within the geo-pedological groups identified in 242 order to discuss the discriminating power of the obtained classification in terms of total 243 Si topsoil concentrations.

244 In order to understand the meaning of the relations between total $\mathrm{Si}_{\text {tot }}$ and $\mathrm{Si}_{\mathrm{CaCl} 2}$ 245 obtained for the different parent material domains, we ran a principal component 246 analysis (PCA) on all the soil characteristics available in the RMQS database, with total 247 Si was considered a passive variable. 

pedological classes

251 For soils developed on sedimentary rocks, we observed as expected a strong negative correlation between $\mathrm{Si}_{\text {tot }}$ and carbonate contents for soils with carbonates concentration higher than $5 \%$ (Figure 1a). This negative correlation was interpreted as a diluting effect of silicate minerals by carbonates. We then sorted geo-pedological classes for soils developed on sediment in carbonated soils developed on sediments and non-carbonated soils developed on sediment (Figure 1b) in order to use this classification in the DSM approach. Based on this separation and on other parent material classes (igneous intrusive and extrusive rocks, metamorphic rock), a boxplot analysis confirmed that this first separation was meaningful (Figure 2) with the highest concentrations in $\mathrm{Si}_{\text {tot }}$ for Podzol topsoils and the lowest for topsoils on igneous extrusive rocks. This low concentration obtained for igneous extrusive rocks may seem surprising as Gray et al. (2016) showed that both Si rich (rhyotite) and Si poor (basalt, andesite) rocks could be found in that group. However, in the case of France, igneous extrusive rocks that are poorly abundant (only 28 sites over 2000) consist mainly in basalt, slag, tuff and other basic volcanic rocks while rhyolite and other acid volcanic rocks are rare (only two sites over the 28 classified as igneous extrusive volcanic 267 rocks).

268 At last, some parent material classes while significantly different from others, still exhibit a very large Si concentration variability, justifying the further classification 270 performed on parent material and soil type criteria (Fig. 3). In this figure, we observe

271 that Podzol topsoils on sedimentary parent materials exhibited significantly higher $\mathrm{Si}_{\text {tot }}$ 272 ( $p$-value = 8.573e-06; Fig. 3). These Podzols are located in two main areas in France, 
273 namely the Landes of Gascony (in southwest France) and an area in central France

274 north of the Massif Central mountains (Figure 4). The Landes of Gascony was entirely 275 covered by aeolian sands (their texture is usually more than $95 \%$ sand; Augusto et 276 al., 2010) that were nearly pure quartz grains (300-550 $\mu \mathrm{m}$ in size) and therefore could 277 be considered as a reference for nearly pure Si topsoils. The other area in central 278 France corresponded to an ancient delta of the Loire River, with very sandy material 279 also quartz rich originating from the erosion of the ancient Massif Central and its 280 northern foothills. Our results are in a good agreement with those of Gray et al. (2016) 281 showing that dune sands were among the richest parent material in $\mathrm{Si}$.

282 On igneous extrusive rock, andosol topsoils exhibited significantly lower $\mathrm{Si}_{\text {tot }}$ than 283 those of other soil types ( $p$-value $<0.001$; Figure 3$)$. For topsoils on metamorphic rock, 284 poorly differentiated soils (Lithosols, Regosols, and Rankers) differed from well 285 differentiated soils (Planosols, Luvisols, and Podzoluvisols), with Cambisols and 286 Fluvisols being intermediate (Figure 3). These three groups of topsoils significantly 287 differed in their $\mathrm{Si}_{\text {tot }}(p$-value $<0.001$ and post-hoc test with a $p$-value $<0.05)$. Soils on 288 sedimentary rocks were the more abundant, and their situation was more complex. 289 Nineteen and seventeen groups were identified either on the basis of both the parent 290 material and the soil type for the carbonated and non-carbonated soils, respectively. 291 These groups differed in their topsoil $\mathrm{Si}_{\text {tot }}(p$-value $<0.001$ for the carbonated soils and $292 p$-value < 0.001 for the non-carbonated soils; Figure 3). As an example, very low 293 concentrations of topsoil $\mathrm{Si}_{\text {tot }}$ were found for poorly differentiated soils on chalk (Fig 3) 294 i.e. nearly pure $\mathrm{CaCO}_{3}$ with $\mathrm{Si}_{\text {tot }}$ close to zero. These soils are encountered mainly in 295 two areas in France: in the Champagne area and in the Charentes (in western France) 296 where soils are locally called Champagne's soils (Figure 4). 
297 Interestingly, this analysis showed that some carbonated soils could exhibit very high

$298 \mathrm{Si}_{\text {tot }}$ in their topsoils, despite the relative absence of $\mathrm{Si}$ in carbonates (e.g. calcic 299 cambisols on other sediments and solonchack; Figure 3). This classification was used 300 in the DSM approach as a covariate along with climate, vegetation using land use, and 301 relief variables.

3.2 Impact of environmental factors (climate and land use) on the total Si concentrations of the French top soils

The covariate importance from the RF algorithm are presented in Figure 5. Two groups of covariates stood out with a threshold of around $20 \%$. The first group contained six environmental covariables. The first covariate, called PG, corresponded as expected to the pedogeological classes previously defined. This covariable made a significant contribution in the model construction, as it exhibited a mean increase in accuracy of $55 \%$. Next was the elevation ("srtm") with an importance of $33 \%$, followed by the NDVI covariate ("PC1_NDVI") and the type of climate ("typo") with an importance of $27 \%$ and $24 \%$, respectively. Finally, the annual mean evapotranspiration ("etp_mean") and the net primary production ("NPP_max") presented an importance of $22 \%$ and $21 \%$, respectively. NDVI covariate is not an independent variable. Indeed, as demonstrated by Loiseau et al. (2019), beside land use, NDVI is partially linked to pedology and climate. Elevation is also not an independent variable in the case of France. For instance, in the case of the Massif Central, igneous extrusive rocks only located at the highest altitude Elevation can be a proxy for both climate and geology in France. Thus, after parent material and soil type, climate seemed to be an important factor in determining the total topsoil Si concentration. 
321 Figure 6 presents $\mathrm{Si}_{\text {tot }}$ as a function of the annual rainfall for the different parent

322 material domains. For carbonated soils on sediments, $\mathrm{Si}_{\text {tot }}$ was independent from

323 annual rainfall as well as non-carbonated soils developed on sedimentary parent

324 materials. A significant negative correlation was obtained for soils on other parent 325 materials, with higher $\mathrm{Si}_{\text {tot }}$ for lower annual rainfall. This correlation was highly 326 significant with the exception of the soils developed on igneous extrusive rocks. The 327 latter being represented by fewer individuals $(n=28)$ than the other groups, a 328 correlation significant only at a $5 \%$ confidence level was acceptable. Such a negative 329 correlation between the concentration in $\mathrm{Si}_{\text {tot }}$ and the average annual rainfall was 330 interpreted as resulting from the increasing losses of Si with an increase in weathering 331 intensity owing to the larger water flow through the soil (higher rainfall). Therefore, the 332 analysis of surface soils may be used as an alternative to the river chemistry (Bluth 333 and Kump (1994) to document the effect of climate on Si weathering.

334 The impact of land use on $\mathrm{Si}_{\text {tot }}$ in French topsoils was tested on the geo-pedological 335 classes defined on Figure 3. To do so, for each class sites were sorted in two land use 336 groups, namely permanent vegetation (forests and pasture) and arable land. We then 337 performed a two-way ANOVA with an interaction term between land use and geology 338 followed by a tukey HSD test. The results showed that the interaction effect was slightly 339 significant $(p=0.012)$. We investigated also the model coefficients and we found that 340 for most of them, the $95 \%$ confidence intervals overlapped except for a few cases. 341 (see $p$-values reported in supplementary material).

342 Lastly, neither the relief nor the landuse could be clearly identify as a factor impacting 343 total Si concentration in soils at least at this scale. Concerning relief, all the proxies of 344 the landforms had a very low weight in this analysis (Figure 4d). For landuse, our data 
345 could not document the positive or negative effect of agriculture, at this scale, on the

346 intensity of silicate weathering that has been suggested in the literature (Struyf et al., 347 2010; Yang and Zhang, 2018).

\subsection{Relationship between $\mathrm{Si}_{\text {tot }}$ and $\mathrm{Si} \mathrm{CaCl}_{2}$ in French} topsoils.

When considering the total dataset (Table 2), a significantly different from 0 , negative

correlation between $\mathrm{Si}_{\mathrm{CaCl} 2}$ and $\mathrm{Si}_{\text {tot }}$ was given but the coefficient is weak $(r=-0.32)$.

While considering the different classes, $\mathrm{Si}_{\mathrm{CaCl}}$ and $\mathrm{Si}_{\text {tot }}$ were also weakly negatively correlated and significantly different from 0 for soils on metamorphic rocks. The negative correlation was moderate $(r=-0.41)$ for non-carbonated soils on sediments, very weak $(r=-0.16)$ and poorly significant for soils on igneous intrusive rocks and non significant for soils on igneous extrusive rocks. Such a negative trend was already observed in other continents by Yanai et al. (2016) and Meunier et al. (2017).

Nevertheless this negative correlation between $\mathrm{Si}_{\mathrm{CaCl}}$ by $\mathrm{Si}_{\text {tot }}$ was not robust enough to be used as a proxy for PAS. However, the correlation for podzol was stronger than the previous ones $(r=-0.75)$ and for carbonated soils on sediments, a positive nonsignificant correlation was obtained. PCA (Figure 7) allowed disentangling the observed correlation between $\mathrm{Si}_{\text {tot }}$ and various soil characteristics for the different soil/parent material classes. $\mathrm{Si}_{\text {tot }}$ was correlated positively with sand and negatively with clay for Podzols showing that the content of sand was mainly composed of quartz,

365 a poorly soluble mineral. Therefore, the best negative correlation given for podzols between $\mathrm{Si}_{\mathrm{CaCl} 2}$ and $\mathrm{Si}_{\text {tot }}$ was interpreted as the presence of quartz as the dominant 367 mineral, which control the poorly soluble pool of $\mathrm{Si}_{\text {tot }}$. For soils on igneous and 368 metamorphic rocks and non-carbonated soils on sediments, sands were associated 369 with elements such as $\mathrm{K}$ or $\mathrm{Na}$, which may be interpreted as the presence of feldspars, 
370 more soluble than quartz and explain the weak correlation between $\mathrm{Si}_{\mathrm{CaCl} 2}$ and $\mathrm{Si}_{\text {tot }}$.

371 Besides, the elements opposed to $\mathrm{Si}_{\text {tot }}$ in the PCA may indicate pools of minerals, 372 which are more favorable to PAS, such as the finer fractions and $\mathrm{Al}$ and Fe oxides 373 (Yanai et al., 2016). For metamorphic rocks for instance, $\mathrm{Si}_{\text {tot }}$ was negatively correlated 374 to $\mathrm{Fe}$ and $\mathrm{Al}$ concentration as seen by the second axis of the PCA (21\% of the 375 variance), but independent from sand content. This axis expressed a quartz content 376 opposed to a secondary mineral content (represented by $\mathrm{Al}$ and $\mathrm{Fe}$ ) and was 377 independent from the sand content since loess deposits are frequent on metamorphic 378 rocks in the Britany region, one of the largest area of metamorphic rocks in France 379 (Lemercier et al., 2011). For carbonated soils on sediments, the PCA showed that $\mathrm{Si}_{\text {tot }}$ 380 were negatively correlated to $\mathrm{Ca}$ (carbonates) and positively correlated to the sand 381 content along the second axis that represented $20 \%$ of the variability. This axis 382 showed that $\mathrm{Si}$ is probably mainly contained in feldspar rather than quartz for 383 explaining the positive trend between topsoil $\mathrm{Si}_{\mathrm{CaCl} 2}$ and $\mathrm{Si}_{\text {tot. }}$. Thus, $\mathrm{Si}_{\text {tot }}$ may be a good 384 proxy for $\mathrm{Si}_{\mathrm{CaCl} 2}$ in the cases of podzols, but for the other soil classes a more detailed 385 analysis of the parameters that control $\mathrm{Si}_{\mathrm{CaCl} 2}$ should be done.

3864 Conclusions

387 In a territory as diverse as France, we showed that the total topsoil Si concentrations

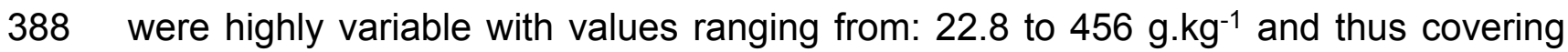
389 almost the entire range of soil Si concentration recorded in the literature so far.

390 The spatial variability in total topsoil Si concentrations was as expected due to the 391 diversity of parent material and soil types. However, climate, notably through the 392 impact of rainfall on weathering intensity, was identified as a driving factor for non393 carbonated soils. No impact of land use and relief could be identified, as well as no 
394 impact of the relief at least at this scale. Further work based on a paired site approach 395 in different pedo-geological contexts is needed to better conclude on the impact of 396 these factors on the total topsoil Si concentrations.

397 Lastly, topsoil $\mathrm{Si}_{\mathrm{CaCl}}$ tended to decrease when topsoil $\mathrm{Si}_{\text {tot }}$ increase. The relationship 398 was the strongest in Podzols where Si was mainly contained in quartz. For the other 399 soil classes, we suggest that $\mathrm{Si}_{\text {tot }}$ may only be considered as a proxy for bioavailable $400 \mathrm{Si}$ if the mineralogical composition is well constrained.

\section{Acknowledgements}

402 This work was performed in the frame of the French ANR BioSiSol project (ANR-14403 CE01-0002). RMQS soil sampling and physico-chemical analyses were supported by 404 the GIS Sol, which is a scientific group of interest on soils involving the French Ministry 405 for ecology and sustainable development and Ministry of agriculture, the French 406 National forest inventory (IFN), ADEME (Agence de l'environnement et de la maîtrise 407 de l'énergie, which is a French government agency concerned with environmental 408 protection and energy management), IRD (Institut de recherche pour le 409 développement, which is a French public research organization dedicated to southern 410 countries) and INRA (Institut national de la recherche agronomique, which is a French 411 public research organization dedicated to agriculture s.l.).

414 Achache, J., Debeglia, N., Grandjean, G., Guillen, A., Le Bel, L., Ledru, P., Renaud, 415 X., Autran, A., Bonijoly, D., Calcagno, P., Pluchery, E., Guennoc, P., Truffert, C., Rossi, 
416 P., Vairon, J., Avouac, J.P., Poli, E., Senechal, G., Brun, J.P., Galdeano, A., Diament,

417 M., Tarits, P., Mervier, J., Paul, A., Poupinet, G., Marquis, G., Bayer, R., Chautra, J.M., 418 1997. GEOFRANCE 3D: l'imagerie géologique et géophysique 3D du sous-sol de la 419 France. Mém. Société Géologique 53-71.

420 Ameijeiras-Marino, Y., Opfergelt, S., Derry, L.A., Robinet, J., Govers, G., Minella, 421 J.P.G., Delmelle, P., 2018. Ge/Si ratios point to increased contribution from deeper 422 mineral weathering to streams after forest conversion to cropland. Applied Geochem. 423 96, 24-34.

424 Baize, D., 2000. Guide des analyses en pédologie, Quae. ed. INRA Editions, Paris 425 (France).

426 Barão, L., Clymans, W., Vandevenne, F., Meire, P., Conley, D.J., Struyf, E., 2014. 427 Pedogenic and biogenic alkaline-extracted silicon distributions along a temperate land428 use gradient. Eur. J. Soil Sci. 65, 693-705.

429 Berner, E.K., Berner, R.A., 1996. Global environment: water, air, and geochemical 430 cycles. Printice Hall, Upper Saddle River, New Jersey.

431 Bluth, G., J., S., Kumpr, L.R., 1994. Lithologic and climatologic controls of river 432 chemistry. Geochim. Cosmochim. Acta 58, 2341-2359.

433 Breiman, L., 2001. Random Forests. Mach. Learn. 45, 5-32. 434 https://doi.org/10.1023/A:1010933404324

435 Cerdan, O., Govers, G., Le Bissonnais, Y., Van Oost, K., Poesen, J., Saby, N., Gobin, 436 A., Vacca, A., Quinton, J., Auerswald, K., Klik, A., Kwaad, F.J.P.M., Raclot, D., Ionita, 437 I., Rejman, J., Rousseva, S., Muxart, T., Roxo, M.J., Dostal, T., 2010. Rates and spatial 
438 variations of soil erosion in Europe: A study based on erosion plot data. 439 Geomorphology 122, 167-177. https://doi.org/10.1016/j.geomorph.2010.06.011

440 Cornelis, J.T., Delvaux, B., 2016. The functional role of silicon in plant biology. Soil 441 processes drive the biological silicon feedback loop. Functional Ecology 30, 12984421310.

443 Coskun, D., Deshmukh, R., Sonah, H., Menzies, J.G., Reynolds, O., Ma, J.F., 444 Kronzucker, H.J., Bélanger, R.R., 2019. The controversies of silicon's role in plant 445 biology. New Phytologist 221, 67-85.

446 De Vos, W., Tarvainen, T., Salminen, R., Reeder, S., De Vivo, B., Demetriades, A., 447 Pirc, S., Batista, M.J., Marsina, K., Ottesen, R.T., 2006. Geochemical atlas of Europe. 448 Part 2. Interpret. Geochem. Maps Addit. Tables Fig. Maps Relat. Publ. Geol. Surv. Finl. 449 Espoo.

450 Dere, A.L., White, T.S., April, R.H., Brantley, S.L., 2016. Mineralogical transformations 451 and soil development in shale across a latitudinal climosequence. Soil Sci. Soc. Am. 452 J. 80, 623-636.

453 Dürr, H.H., Meybeck, M., Hartmann, J., Laruelle, G.G., Roubeix, V., 2011. Global 454 spatial distribution of natural riverine silica inputs to the coastal zone. Biogeosciences $455 \quad 8,5978-620$

456 Egli, M., Mirabella, A., Sartori, G., Fitze, P., 2003. Weathering rates as a function of 457 climate: results from a climosequence of the Val Genova (Trentino, Italian Alps), 458 Geoderma 111, 99-121. 
459 European Environment Agency, 2007. CLC2006 technical guidelines. Publications 460 Office, Luxembourg.

461 Faroux, S., Kaptué Tchuenté, A.T., Roujean, J.-L., Masson, V., Martin, E., Moigne, 462 P.L., 2013. ECOCLIMAP-II/Europe: A twofold database of ecosystems and surface 463 parameters at $1 \mathrm{~km}$ resolution based on satellite information for use in land surface, 464 meteorological and climate models. Geosci. Model Dev. 6, 563-582.

465 Frings, P.J., Clymans, W., Fontorbe, G., Gray, W., Chakrapani, G.J., Conley, D.J., De 466 La Rocha, C., 2015. Silicate weathering in the Ganges alluvial plain. Earth Planet. Sci. 467 Let. $427,136-148$.

468 Gray, J.M., Bishop, T.F.A., Wilford, J.R., 2016. Lithology and soil relationship for soil 469 modelling and mapping. Catena 147, 429-440.

470 Lucas, Y., Luizao, F.J., Chauvel, A., Rouiller, J., Nahon, D., 1993. The relation between 471 biological activity of the rain forest and mineral composition of soils. Science $260,521-$ 472523.

473 Matheron, G., 1971. The Theory of Regionalised Variables and its Applications. Cah. 474 Cent. Morphol. Math. 5, 212.

475 Gneiting, T., Balabdaoui, F., Raftery, A.E., 2007. Probabilistic forecasts, calibration 476 and sharpness. J. R. Stat. Soc. Ser. B Stat. Methodol. 69, 243-268.

477 Guntzer, F., Keller, C., Poulton, P.R., McGrath, S.P., Meunier, J.-D., 2012. Long-term 478 removal of wheat straw decreases soil amorphous silica at Broadbalk, Rothamsted. 479 Plant Soil 352, 173-184. 
480 Haysom, M.B.C., Chapman, L.S.,1975. Some aspects of the calcium silicate trials at 481 Mackay. Proc. Qld. Soc. Sugar Cane Technol. 42, 117-122.

482 Henriet, C., Bodarwé, L., Dorel, M., Draye, X., Delvaux, B., 2008. Leaf silicon content 483 in banana (Musa spp.) reveals the weathering stage of volcanic ash soils in 484 Guadeloupe. Plant Soil 313, 71.

485 Hijmans, R.J., Cameron, S.E., Parra, J.L., Jones, P.G., Jarvis, A., 2005. Very high 486 resolution interpolated climate surfaces for global land areas. Int. J. Climatol. 25, 1965487 1978. https://doi.org/10.1002/joc.1276

488 Huete, A., Didan, K., Miura, T., Rodriguez, E.P., Gao, X., Ferreira, L.G., 2002. 489 Overview of the radiometric and biophysical performance of the MODIS vegetation 490 indices. Remote Sens. Environ., The Moderate Resolution Imaging Spectroradiometer 491 (MODIS): a new generation of Land Surface Monitoring 83, 195-213. 492 https://doi.org/10.1016/S0034-4257(02)00096-2

493 Institut National de l'Information Géographique et Forestière, 2006. Base de Données 494 Forêt.

495 James, G., Witten, D., Hastie, T., Tibshirani, R., 2013. An Introduction to Statistical 496 Learning, Springer Texts in Statistics. Springer New York, New York, NY. 497 https://doi.org/10.1007/978-1-4614-7138-7

498 Jolivet, C., Arrouays, D., Boulonne, L., Ratié, C., Saby, N., 2006. Le réseau de 499 mesures de la qualité des sols de France (RMQS). Etat D'avancement Prem. Résultats 500 Etude Gest. Sols 13, 149-164. 
501 Joly, D., Brossard, T., Cardot, H., Cavailhes, J., Hilal, M., Wavresky, P., 2010. Les

502 types de climats en France, une construction spatiale. Cybergeo Eur. J. Geogr. 503 https://doi.org/10.4000/cybergeo.23155

504 Keskin, H., Grunwald, S., 2018. Regression kriging as a workhorse in the digital soil 505 mapper's toolbox. $\quad$ Geoderma $22-41$. 506 https://doi.org/10.1016/j.geoderma.2018.04.004

507 King, D., Jones, R.J.A., Thomasson, A.J., 1995. European land information systems 508 for agro-environmental monitoring.

509 Kuhn, M., Steve, W., Chris, K., Nathan, C., code), R.Q. (Author of imported C., code), 510 R.R.P.L. (Copyright holder of imported C., 2017. Cubist: Rule- And Instance-Based 511 Regression Modeling.

512 Kursa, M.B., 2014. Robustness of Random Forest-based gene selection methods. 513 BMC Bioinformatics 15, 8. https://doi.org/10.1186/1471-2105-15-8

514 Kursa, M.B., Rudnicki, W.R., 2010. Feature selection with the Boruta package. J Stat 515 Softw 36, 1-13.

516 Landré, A., Saby, N.P.A., Barthès, B.G., Ratié, C., Guerin, A., Etayo, A., Minasny, B., 517 Bardy, M., Meunier, J.-D., Cornu, S., 2018. Prediction of total silicon concentrations in 518 French soils using pedotransfer functions from mid-infrared spectrum and pedological 519 attributes. Geoderma 331, 70-80.

520 Le Bas, C., Barthès, S., Boutefoy, I., Fort, J., Scheurer, O., Darracq, S., Lacassin, J., 521 Sauter, J., 2004. Utilisation des données sols d'I.G.C.S. en France : Un état des lieux. 522 Étude Gest. Sols (2), 8. 
523 Liang, Y., Nikolic, M., Bélanger, R., Gong, H., Song, A., 2015. Silicon in agriculture.

524 Dordr. Springer Doi 10, 978-94.

525 Liaw, A., Wiener, M., 2002. Classification and Regression by randomForest 2, 6.

526 Loiseau, T., Chen, S., Mulder, V.L., Román Dobarco, M., Richer-de-Forges A.C.,

527 Lehmann, S., Bourennane, H., Saby N.P.A., Martin, M.P., Vaudour, E., Gomez, C.4

528 Lagacherie, P., Arrouays D. 2019, Satellite data integration for soil clay content 529 modelling at a national scale, International Journal of Applied Earth Observations and 530 Geoinformation, 82,108205

531 Magidson, J., 1981. Qualitative variance, entropy, and correlation ratios for nominal 532 dependent variables. Soc. Sci. Res. 10, 177-194. https://doi.org/10.1016/0049$533 \quad 089 \times(81) 90003-X$

534 McBratney, A.B., Santos, M.M., Minasny, B., 2003. On digital soil mapping. Geoderma $535117,3-52$.

536 Meunier, J.D., Sandhya, K., Prakash, N. B., Borschneck, D., Dussouillez, P., 2018. $537 \mathrm{pH}$ as a proxy for estimating plant-available Si? A case study in rice fields in Karnataka 538 (South India). Plant and Soil 432, 143-155.

539 Minasny, B., McBratney, A.B., 2006. A conditioned Latin hypercube method for 540 sampling in the presence of ancillary information. Comput. Geosci. 32, 1378-1388.

541 Minasny, B., McBratney, A.B., Hartemink, A.E., 2010. Global pedodiversity, taxonomic 542 distance, and the World Reference Base. Geoderma 155, 132-139. 543 https://doi.org/10.1016/j.geoderma.2009.04.024 
544 Minasny, B., Tranter, G., McBratney, A.B., Brough, D.M., Murphy, B.W., 2009.

545 Regional transferability of mid-infrared diffuse reflectance spectroscopic prediction for

546 soil chemical properties. Geoderma 153, 155-162.

547 https://doi.org/10.1016/j.geoderma.2009.07.021

548 Moriasi, D.N., Arnold, J.G., Liew, M.W.V., Bingner, R.L., Harmel, R.D., Veith, T.L., 549 2007. Model Evaluation Guidelines for Systematic Quantification of Accuracy in 550 Watershed Simulations. Trans. ASABE $\quad$ 50, 885-900.

551 https://doi.org/10.13031/2013.23153

552 Mulder, V.L., Lacoste, M., Richer-de-Forges, A.C., Arrouays, D., 2016. GlobalSoilMap 553 France: High-resolution spatial modelling the soils of France up to two meter depth. 554 Sci. Total Environ. 573, 1352-1369. https://doi.org/10.1016/j.scitotenv.2016.07.066

555 Narayanaswamy, C., Prakash, N.B., 2010. Evaluation of selected extractants for plant556 available silicon in rice soils of Southern India. Comm. Soil Sc. PI Anal., 41, 977-989.

557 Nash, J.E., Sutcliffe, J.V., 1970. River flow forecasting through conceptual models part 558 I - A discussion of principles. J. Hydrol. 10, 282-290. https://doi.org/10.1016/0022559 1694(70)90255-6

560 NCAR-Research Applications Laboratory, 2015. verification: Weather Forecast 561 Verification Utilities.

562 Pebesma, E., Graeler, B., 2019. gstat: Spatial and Spatio-Temporal Geostatistical 563 Modelling, Prediction and Simulation.

564 Quinlan, J.R., 1992. Learning with continuous classes, in: 5th Australian Joint 565 Conference on Artificial Intelligence. Singapore, pp. 343-348. 
566 Quintana-Seguí, P., Le Moigne, P., Durand, Y., Martin, E., Habets, F., Baillon, M.,

567 Canellas, C., Franchisteguy, L., Morel, S., 2008. Analysis of Near-Surface 568 Atmospheric Variables: Validation of the SAFRAN Analysis over France. J. Appl.

569 Meteorol. Climatol. 47, 92-107. https://doi.org/10.1175/2007JAMC1636.1

570 R. Core Team, 2016. R: A language and environment for statistical computing. Version 571 3.3. 1. 2016.

572 Reimann, C., Birke, M., Demetriades, A., Filzmoser, P., O’Connor, P., 2014. Chemistry 573 of Europe's agricultural soils, part A.

574 Rodrigues, F.A., Datnoff, L.E., 2015. Silicon and plant diseases. Springer.

575 Roudier, P., 2017. clhs: Conditioned Latin Hypercube Sampling.

576 Siegel, S., Castellan, N.J., 1988. Nonparametric Statistics for the Behavioral Science, 577 2nd edition. ed. McGraw-Hill Education, New York; etc.

578 Sommer, M., Kaczorek, D., Kuzyakov, Y., Breuer, J., 2006. Silicon pools and fluxes in 579 soils and landscapes-a review. J. Plant Nutr. Soil Sci. 169, 310-329. 580 https://doi.org/10.1002/jpln.200521981

581 Struyf, E., Smis, A., Van Damme, S., Garnier, J., Govers, G., Van Wesemael, B., 582 Conley, D.J., Batelaan, O., Frot, E., Clymans, W., 2010. Historical land use change 583 has lowered terrestrial silica mobilization. Nat. Commun. 1, 129.

584 Taboada, T., Ferro-Vazquez, C., Stoops, G., Martinez Cortizas, A., Rodriguez Flores, 585 R., Rodriguez-Laco, L., 2019. Secondary aluminium, iron and silica phases across a 
586 volcanic soil climosaquence, Galapagos Islands. Europ. J. Soil Sci., 70, 587 https://doi.org/10.1111/ejss.12788

588 USGS, 2006. Shuttle Radar Topography Mission, 1 Arc Second Scene 589 SRTM_u03_n008e004, Unfilled Unfinished 2.0. Shuttle Radar Topography Mission.

590 Vandevenne, F.O., Barao, L., Ronchi, B., Govers, G., Meire, P., Kelly, E.F., Struyf., E., 591 2015. Silicon pools in human impacted soils of temperate zones. Global Geochemical 592 Cycles, 29, doi:10.1002/2014GB005049.

593 Viscarra Rossel, R.A., Walvoort, D.J.J., McBratney, A.B., Janik, L.J., Skjemstad, J.O., 594 2006. Visible, near infrared, mid infrared or combined diffuse reflectance spectroscopy 595 for simultaneous assessment of various soil properties. Geoderma 131, 59-75. 596 https://doi.org/10.1016/j.geoderma.2005.03.007

597 Wedepohl, K.H., 1995. The composition of the continental crust. Geochim. 598 Cosmochim. Acta 59, 1217-1232.

599 White, A. F., Vivit, D.V., Shulz, M. S., Bullen, T.D., Evett, R.R., Aagarwal, J., 2012. 600 Biogenic and pedogenic controls on Si distributions and cycling in grasslands of the 601 Santa Cruz soil chronosequence, California. Geochim. Cosmochim. Acta 94, 72-94.

602 Yanai, J., Taniguchi, H., Nakao, A., 2016. Evaluation of available silicon content and 603 its determining factors of agricultural soils in Japan. Soil Sci. Plant Nutr. 62, 511-518.

604 Yang, J.L., Zhang, G.L., 2018. Silicon cycling by plant and its effects on soiil Si 605 translocation in a typical subtropical area. Geoderma 310, 89-98. 
607

608 


\section{Captions}

Figure 1: Variability of $\mathrm{Si}_{\text {tot }}$. (a) Relationship between the concentration in total $\mathrm{Si}$ concentration and in carbonate content in French topsoils. The different soils developed on sedimentary rocks are reported in yellow while those developed on igneous and metamorphic rocks are reported in grey; (b) Separation between carbonated soils and non-carbonated soils on sedimentary rocks based on the geo-pedological classification. All the soil groups with mean carbonate content lower than $5 \%$ were considered as non-carbonated soils.

Figure 2: Boxplots of $\mathrm{Si}_{\text {tot }}$ for the main geological domains and podzols. The boxes represent the interquartile range, the bold horizontal segment the median $\mathrm{Si}_{\text {tot }}$, the whiskers, the $99 \%$ range and the black dots the outliers. Letters above boxplots represent groups with $\mathrm{Si}_{\text {tot }}$ significantly different and numbers, the sample size.

Figure 3: Boxplots of $\mathrm{Si}_{\text {tot }}$ for all the considered pedo-geological groups. The boxes represent the interquartile range, the bold horizontal segment the median $\mathrm{Si}_{\text {tot }}$, the whiskers, the $99 \%$ range and the black dots the outliers. Colors represent distinction of main geological domains plus podzols.

Figure 4: $\mathrm{Si}_{\text {tot }}$ spatial distribution from digital soil mapping approach (DSM).

Figure 5: Variable importance in the random forest Model. The X-axis is the Mean Decrease Accuracy computed as the increase percentage in mean squared error of predictions (estimated with out-ofbag-Cross Validation) as a result of variable $\mathrm{j}$ being permuted. The definition of the environmental covariates are listed in Table 2.

Figure 6: Plots of the total topsoil Si concentration versus the 30 year average of annual rainfall for the different parent material domains. Soils on sedimentary parent materials were sorted according to the nature of the parent material for the carbonated soils (shalk, marl, limestone and other) and of the texture of the parent material for non-carbonated soils (clay, loam, sand). The black lines represent the fitted linear regression. The Pearson correlation is also provided per parent material domains. Stars represents the level of signification of the correlation: one star being significant at a $5 \%$ confidence level, two stars at $1 \%$ and three stars at $1 \%$.

Figure 7: Variables correlation circle for the first two components of the Principal Component Analyzes (PCA) performed for each main geological domain and podzols. In blue, Si considered as a passive variable in these PCAs. 


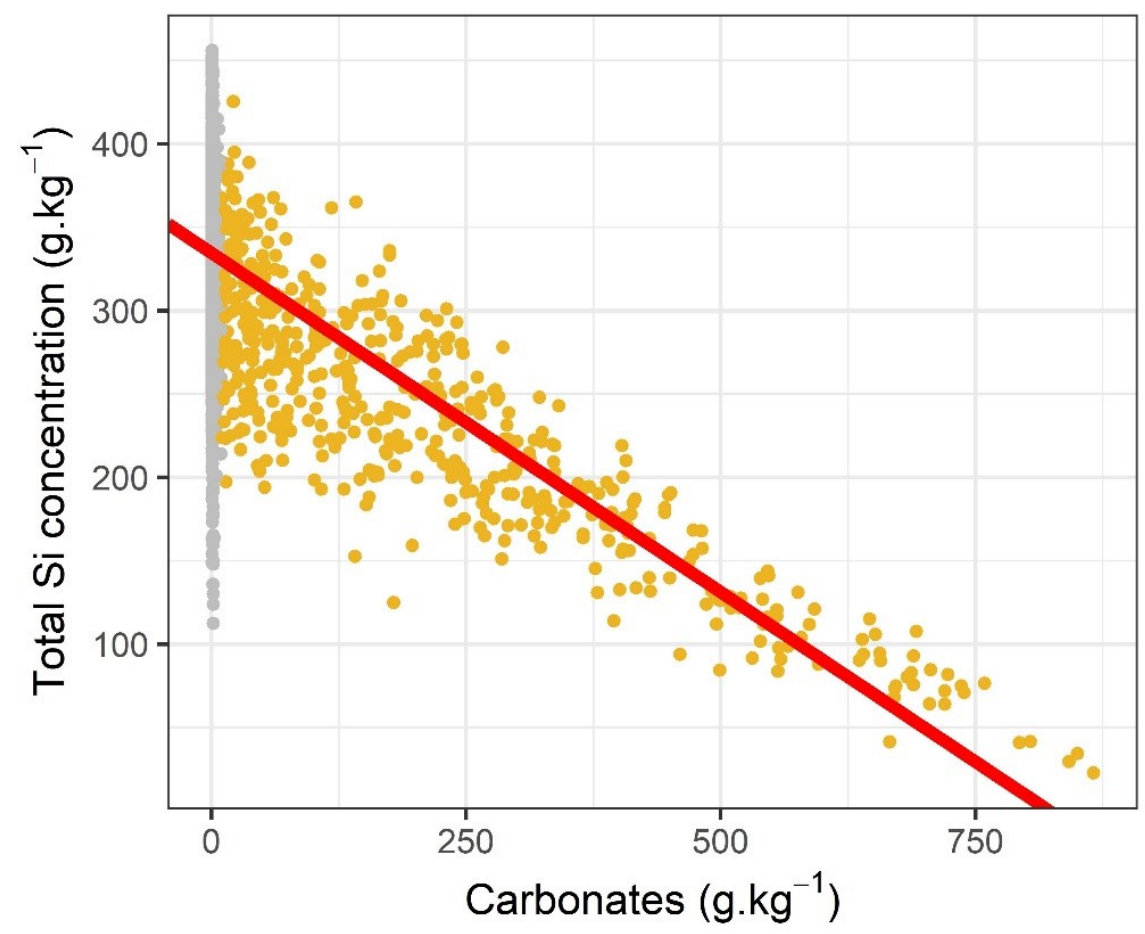

Parental material

- Carbonated soils on sediments

- Other soils

b

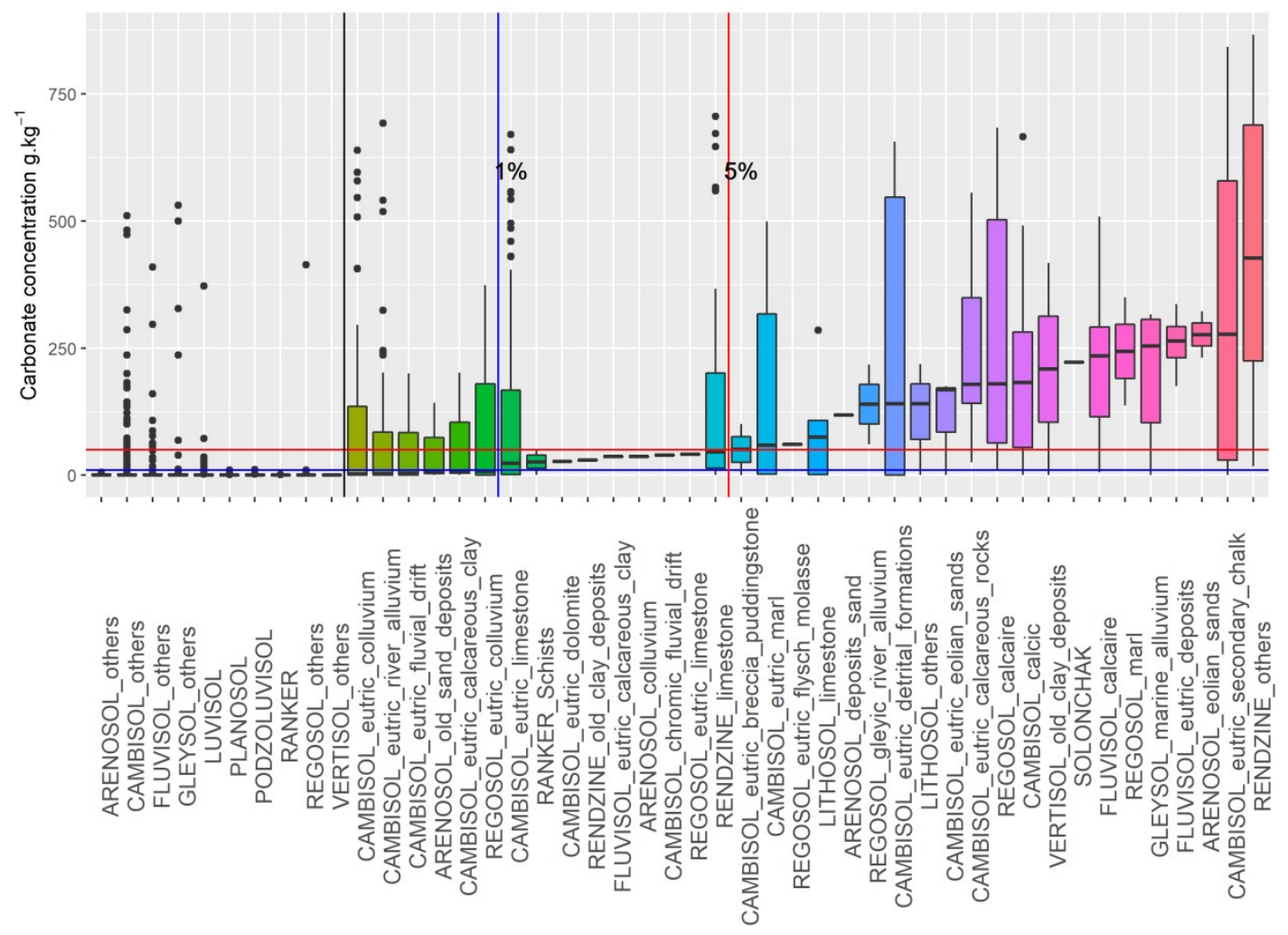

Figure 1 


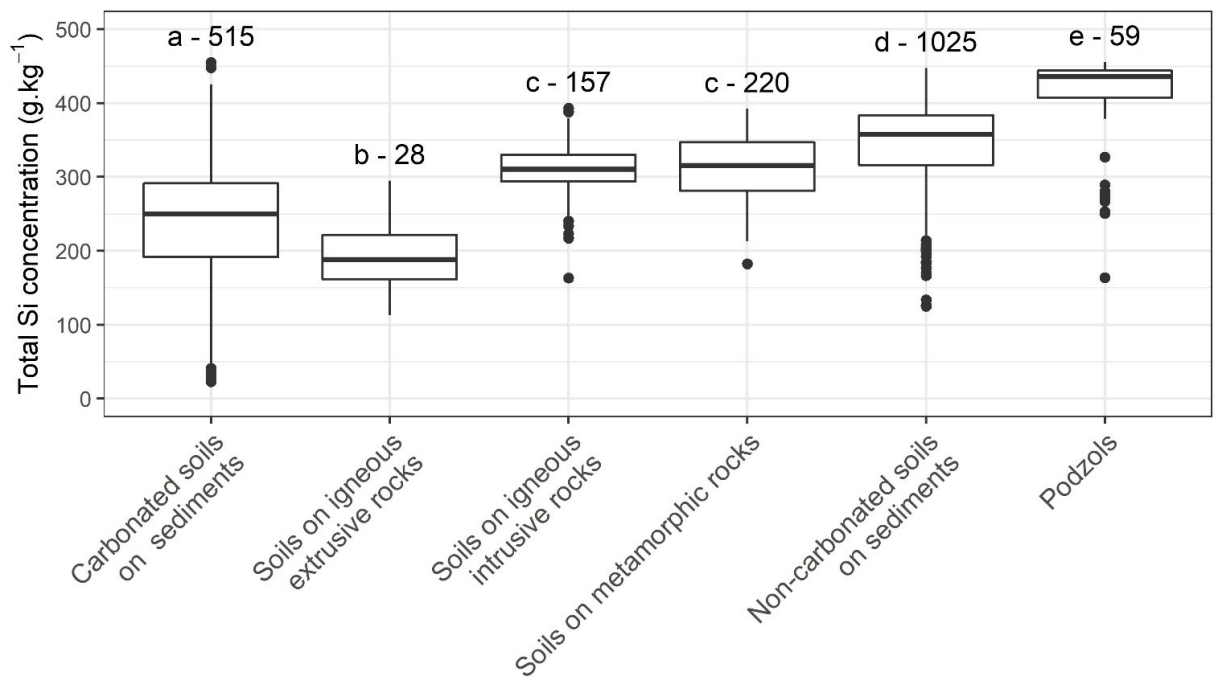

Figure 2 


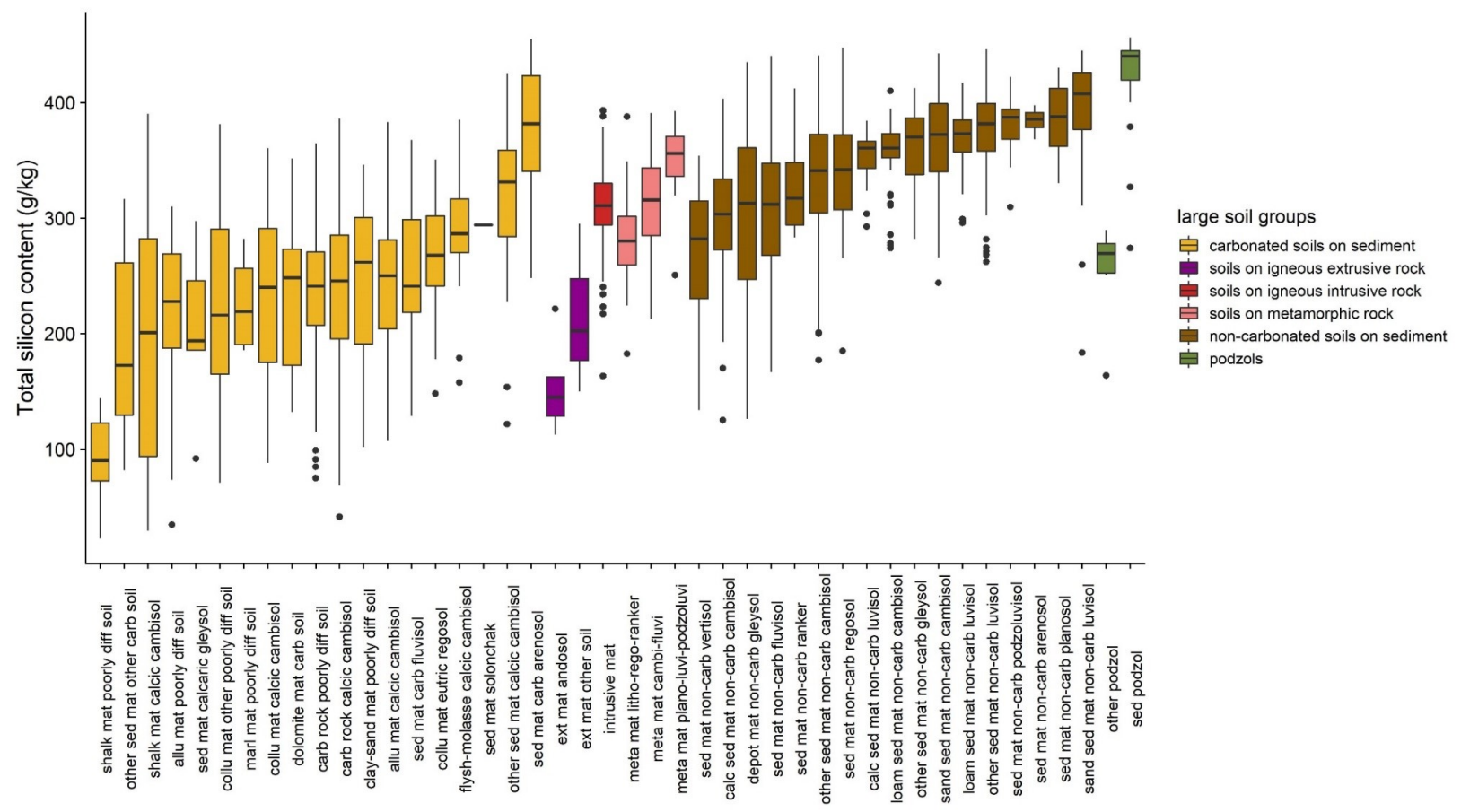

Figure 3 


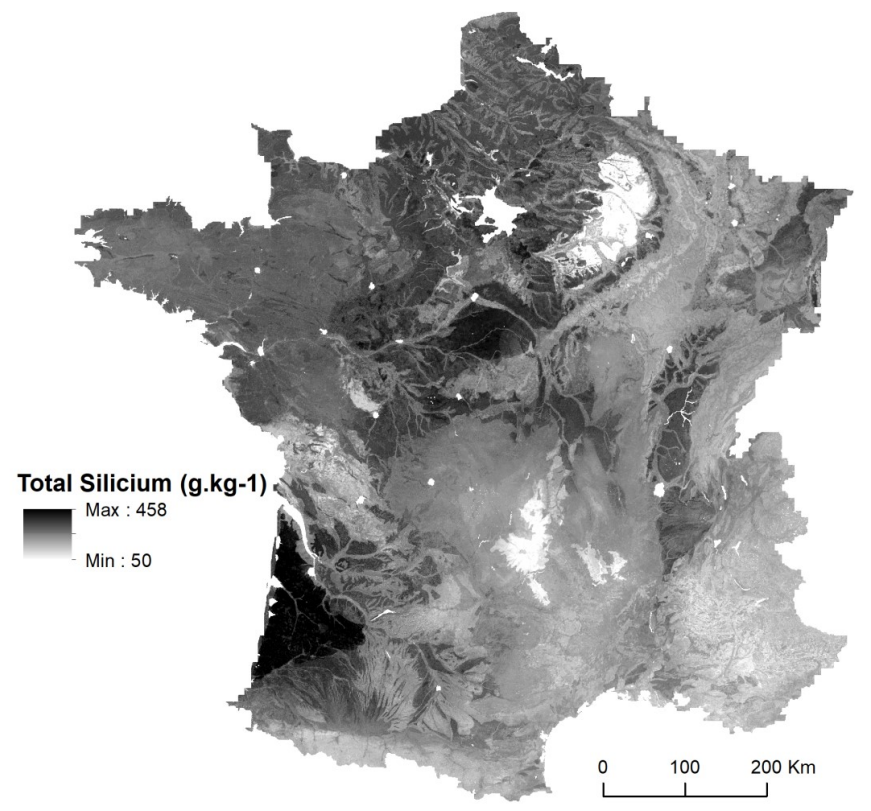

Figure 4 


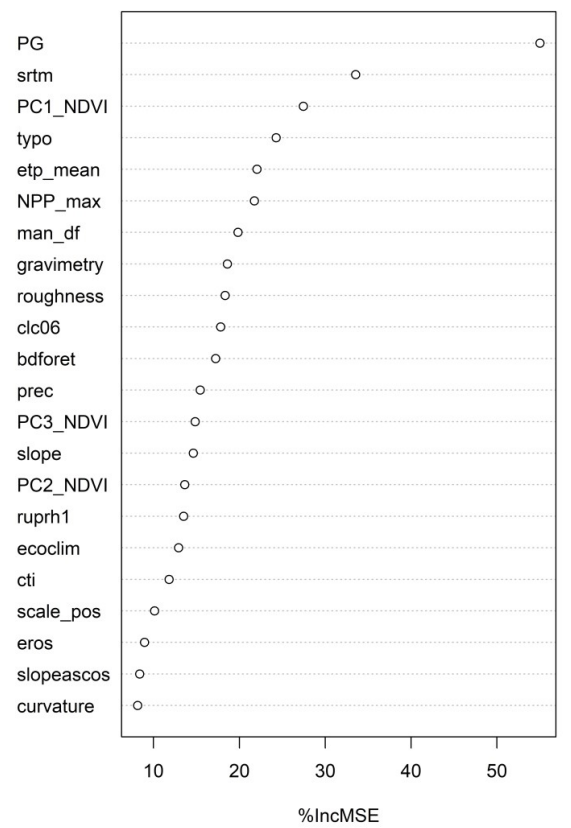

Figure 5 


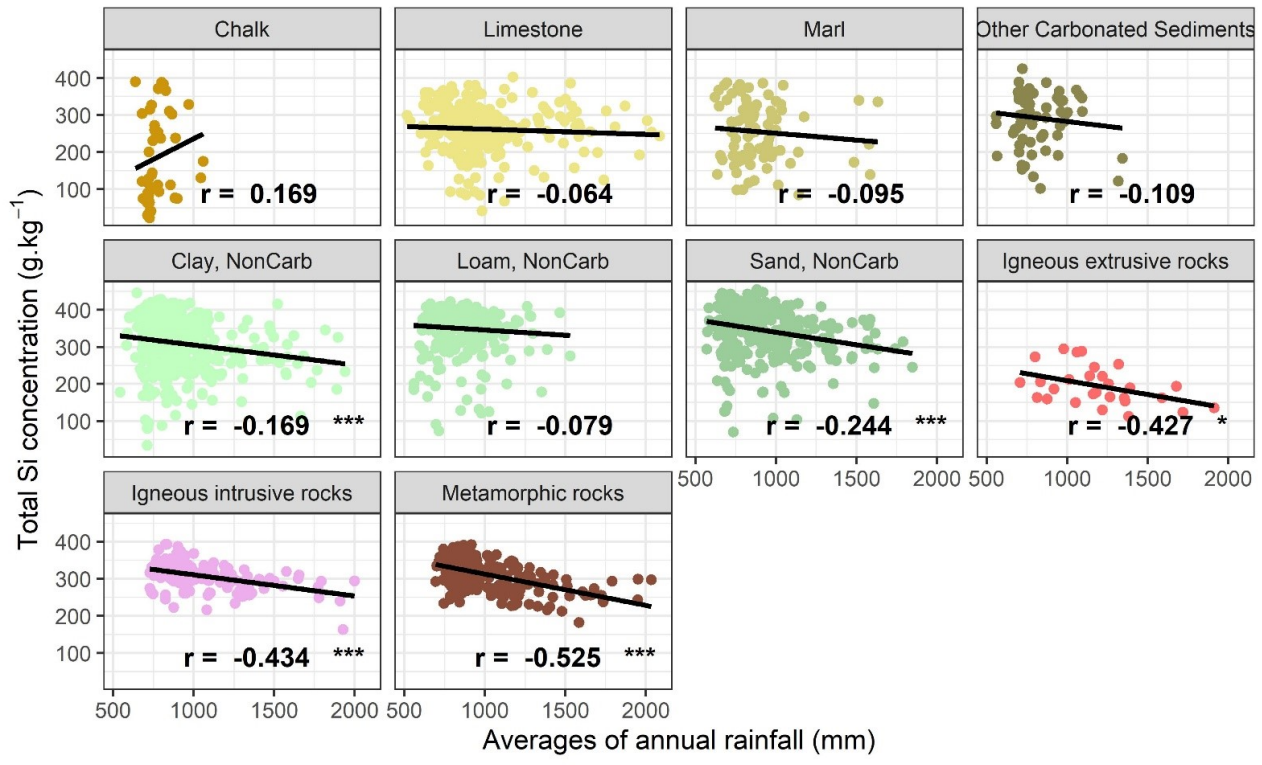

Figure 6 


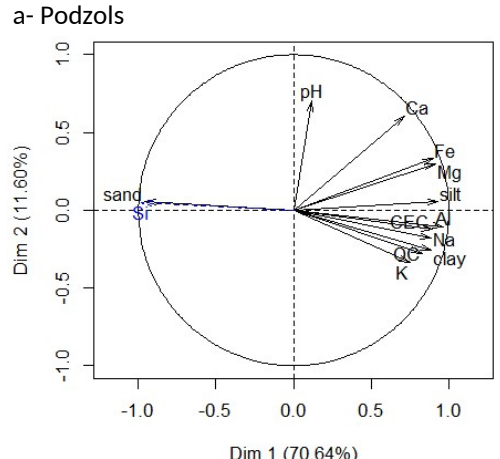

d- Soils on igneous extrusive rocks

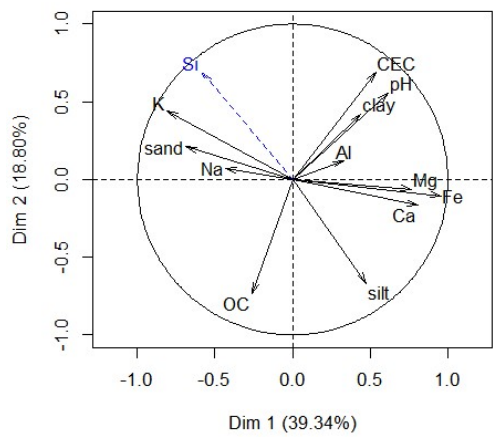

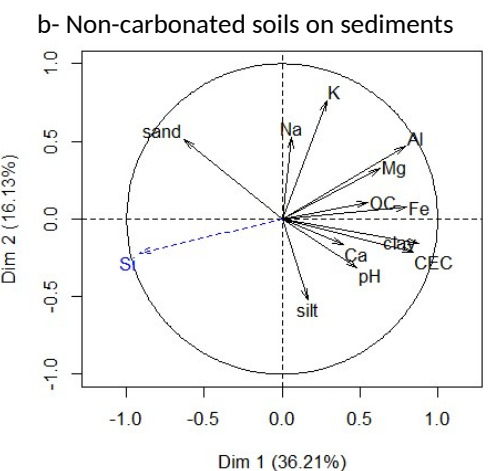

e-Soils on igneous intrusive rocks

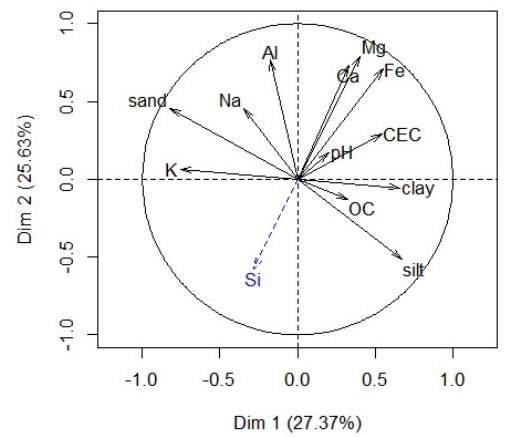

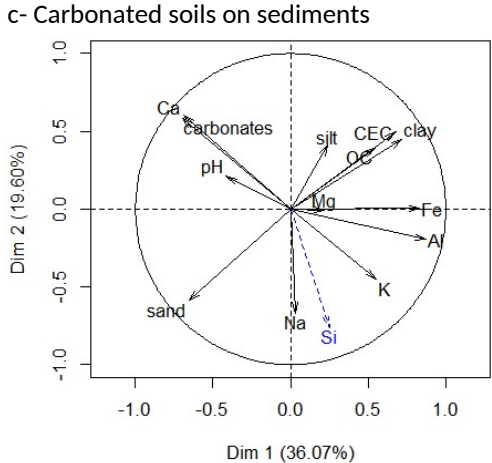

f- Soils on metamorphic rocks

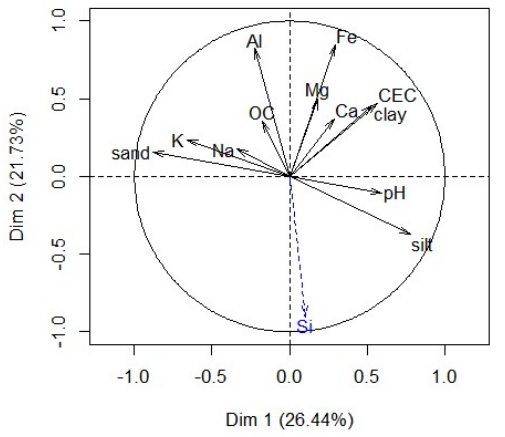

Figure 7 
Table 1: Exhaustive categorical and continuous covariates used for the Digital Soil Mapping approach

\begin{tabular}{|c|c|c|c|c|c|}
\hline $\begin{array}{l}\text { Pedological } \\
\text { factor }\end{array}$ & abreviates & variables & scale & type & Reference \\
\hline \multirow{7}{*}{ Vegetation } & bdforet & Forest type & & category & $\begin{array}{l}\text { Institut National de l'Information } \\
\text { Géographique et Forestière (2006) }\end{array}$ \\
\hline & ecoclim & Ecoclimap land use & $1 \mathrm{~km}$ & category & Faroux et al. (2013) \\
\hline & NPP_max & Net Primary Production & $1 \mathrm{~km}$ & quantitative & LPDAAC (2001) \\
\hline & clc06 & land use (Corine Land Cover) & $250 \mathrm{~m}$ & category & European Environment Agency (2007) \\
\hline & PC1_NDVI & $\begin{array}{l}\text { 1st component of Normalized Difference } \\
\text { Vegetation Index }\end{array}$ & $90 \mathrm{~m}$ & quantitative & Loiseau et al. (2019) \\
\hline & PC2_NDVI & $\begin{array}{l}\text { 2nd component of Normalized Difference } \\
\text { Vegetation Index }\end{array}$ & $90 \mathrm{~m}$ & quantitative & Loiseau et al. (2019) \\
\hline & PC3_NDVI & $\begin{array}{l}\text { 3rd component of Normalized Difference } \\
\text { Vegetation Index }\end{array}$ & $90 \mathrm{~m}$ & quantitative & Loiseau et al. (2019) \\
\hline \multirow{8}{*}{ Relief } & cti & Compound Topographic Index (SRTM) & $90 \mathrm{~m}$ & quantitative & USGS (2006) \\
\hline & roughness & roughness (SRTM) & $90 \mathrm{~m}$ & quantitative & USGS (2006) \\
\hline & curvature & curvature (SRTM) & $90 \mathrm{~m}$ & quantitative & USGS (2006) \\
\hline & scale_pos & slope position (SRTM) & $90 \mathrm{~m}$ & quantitative & USGS (2006) \\
\hline & slope & slope (SRTM) & $90 \mathrm{~m}$ & quantitative & USGS (2006) \\
\hline & slopascos & slope cosinus (SRTM) & $90 \mathrm{~m}$ & quantitative & USGS (2006) \\
\hline & srtm & elevation DEM (SRTM) & $90 \mathrm{~m}$ & quantitative & USGS (2006) \\
\hline & eros & Erosion rate & $1: 1000000$ & quantitative & Cerdan et al. (2010) \\
\hline \multirow{3}{*}{ Climate } & prec & mean annual precipitation & $\sim 1 \mathrm{~km}$ & quantitative & Hijmans et al. (2005) \\
\hline & Typo & climate typology & $250 \mathrm{~m}$ & category & Joly et al. (2010) \\
\hline & etp_mean & mean annual potential evapotranspiration & $8 \mathrm{~km}$ & quantitative & Quintana-Segui et al. (2008) \\
\hline Parent material & gravimetry & free-air Bouguer anomaly & $4 \mathrm{~km}$ & quantitative & Achache et al. (1997) \\
\hline Soil & ruprh1 & available water capacity & $1: 1000000$ & quantitative & Le Bas et al. (2004) \\
\hline $\begin{array}{l}\text { Soil and parent } \\
\text { material }\end{array}$ & PG & Pedological and Geological classification & $1: 1000000$ & category & King et al. (1995) \\
\hline
\end{tabular}


Table 2: Pearson correlation coefficient between $\mathrm{Si}_{\mathrm{CaCl} 2}$ and $\mathrm{Si}_{\text {tot }}$ in French topsoils. Significance levels: ${ }^{* * *}: p$-value $<0.001 ;{ }^{* *}: p$-value $<0.01 ;{ }^{*}: p$ value $<0.05$

\begin{tabular}{|c|c|c|}
\hline Classes & $\mathrm{n}$ & $r$ \\
\hline $\begin{array}{l}\text { Carbonated soils on } \\
\text { sediments }\end{array}$ & 508 & $0.12^{* * *}$ \\
\hline $\begin{array}{l}\text { Soils on igneous extrusive } \\
\text { rocks }\end{array}$ & 28 & -0.25 \\
\hline $\begin{array}{l}\text { Soils on igneous intrusive } \\
\text { rocks }\end{array}$ & 155 & $-0.16^{*}$ \\
\hline Soils on metamorphic rocks & 217 & $-0.26^{* * *}$ \\
\hline $\begin{array}{l}\text { Non-carbonated soils on } \\
\text { sediments }\end{array}$ & 1020 & $-0.41^{* * *}$ \\
\hline Podzols & 58 & $-0.75^{* * *}$ \\
\hline All data & 1986 & $-0.32^{* * *}$ \\
\hline
\end{tabular}




\section{DO RAINFALL AND LAND USE AFFECT THE POOL OF TOTAL SI CONCENTRATION? A DIGITAL SOIL MAPPING APPROACH OF FRENCH TOPSOILS.}

Landré, A. ${ }^{\mathrm{a}, \mathrm{b}}$, Cornu, S.c, Meunier, J.-D. ${ }^{\mathrm{c}}$,Guerin A. ${ }^{\mathrm{d}}$, Arrouays D. ${ }^{\mathrm{a}}$, Caubet M. ${ }^{\mathrm{a}}$, Ratié C. ${ }^{\mathrm{a}}$, , Saby, N.P.A. ${ }^{a}$

a) INRA, Infosol, US 1106, Orléans, France

b) INRA - INPT-ENSAT - INPT-EI-Purpan, UMR 1248 AGIR AGroécologie, Innovations, teRritoires. Centre de recherche Occitanie-Toulouse, Auzeville, France.

c) Aix-Marseille Univ, CNRS, IRD, Coll de France, INRA, CEREGE, Aix-en-Provence, France

d) INRA, Laboratoire d'Analyses des Sols US, Arras, France 


\section{Supplementary file: Determination of the total Si concentration ( $\mathrm{Si}_{\text {tot }}$ ) based on the concentration in major elements}

Landre et al. (2018) analyzed $\mathrm{Si}_{\text {tot }}$ for a subset of 673 samples, among the 2007 RMQS samples. $\mathrm{Si}_{\text {tot }}$ for the remaining sites was modelled using a Cubist modelling approach, as follow:

$$
\mathrm{Si}=\mathrm{f}\left(\mathrm{Al}, \mathrm{Fe}, \mathrm{K}, \mathrm{Na}, \mathrm{Ca}_{\mathrm{nc}}, \mathrm{Mg}_{\mathrm{nc}}, \mathrm{P}, \mathrm{Mn}, \mathrm{OC}, \mathrm{CaCO}_{3}, \text { residual water }\right)(\mathrm{S} 1)
$$

Where $\mathrm{f}$ is the cubist regression trees model,

$C a_{n c}$ and $M g_{n c}$ are the fraction of calcium and magnesium, respectively, that are not included in carbonate minerals nor adsorbed on the exchangeable surfaces. They were estimated as follow

$$
\begin{aligned}
& C a_{n c}=C a_{t o t}-\left(\left(\frac{\mathrm{CCO}_{3}}{10} * 0.401\right)+C a_{\text {exch }}\right) \quad \text { with } \quad C a_{n c} \geq 0 \\
& M g_{n c}=M g_{t o t}-\left(M g_{\text {ech }}+C a_{\text {excess }}\right) \quad \text { with } \quad M g_{n c} \geq 0
\end{aligned}
$$

Where $C a_{\text {excess }}=C a_{n c}$ when $C a_{n c} \leq 0$ and $C a_{n c}=0$ otherwise

The Cubist model is a form of regression rules that build unconventional regression trees, with final nodes containing linear models instead of discrete values (Quinlan, 1992). Cubist creates comprehensible rules that describe the relationships between predictive variables (here spectra or soil properties) and the variable of interest.

In order to calibrate and validate the models, we used a repeated cross-validation approach combined to a bootstrap step (James et al., 2013). Repeated cross-validation allows assessing the quality of the prediction. It involves randomly dividing the available set of data into two parts, a calibration set and a validation set. We repeated this operation 10 times using a split of $75 \%-25 \%$ for calibration and validation respectively. This subdivision was performed using the conditioned Latin Hypercube 
Sampling (cLHS) method (Minasny and McBratney, 2006). This method is a stratified random procedure that provides an efficient way of sampling variables from their multivariate distributions. The bootstrap step allows assessing the uncertainty of the model predictions. For this, we simulated 100 datasets by random sampling with replacement $95 \%$ of the calibration dataset from the crossvalidation step. This procedure provided then 100 Cubist models. The final prediction is obtained by averaging the predictions of 100 bootstrapped models. Our modelling approach involves a large number of calibration and validation operations, and we thus used a parallel processing approach to overcome the computational load. It is implemented in R using the packages foreach, doParrallel or snow. We used the Cubist model implemented in the R package Cubist (Kuhn et al., 2016), the cLHS function implemented in the R package clhs (Roudier, 2011) and the crps function implemented in the R package verification (Laboratory NCAR-Research Applications, 2015).

The model was assessed using three conventional performance indicators: the coefficient of determination $\left(\mathrm{R}^{2}\right)$, the root mean square error (RMSE) also known as standard error of prediction (SEP) and the bias, which is the mean residual of the model. We also took into account the probabilistic characteristic of model predictions by using the continuous rank probability score average (CRPS, equation 6). The CRPS represents the closeness between the prediction distribution and the corresponding observations (Gneiting et al., 2007).

$$
\begin{aligned}
& \text { CRPS }=\int_{-\infty}^{\infty} B S(y) d y \\
& B S(y)=\frac{1}{n} \sum_{i=1}^{n}\left\{\left(F_{i}(y)-\mathbb{1}\left(x_{i} \leq y\right)\right\}^{2}\right. \text { (s5) }
\end{aligned}
$$

Where $B S(y)$ denotes the Brier (1950) score for probability forecasts of the binary event at the threshold value $y \in \mathbb{R}, x$ the observation and $y$ the model prediction, $n$ the number of samples, $F$ the cumulative distribution function (CDF) of $\mathrm{X}$, a random variable, such as $F(y)=P[X \leq y]$ and ?? is the Heaviside step function. This function is a discontinuous function whose value is zero for negative argument and one for positive argument. 
The $\mathrm{Si}_{\text {tot }}$ prediction function is yielding $\mathrm{R}^{2}$ greater than 0.98 with a very small variance $(0.0012)$ among repetitions of the cross-validation, RMSE lower than $11 \mathrm{~g} \mathrm{~kg}^{-1}$ and CRPS lower than $7 \mathrm{~g} \mathrm{~kg}^{-1}$ for measured $\mathrm{Si}_{\text {tot }}$ ranging from 22.81 to $455.8 \mathrm{~g} \mathrm{~kg}^{-1}$ over the RMQS database with a median equal to $323.6 \mathrm{~g} \mathrm{~kg}^{-1}$. These results are better than the results obtained by Landre et al. (2018) with their MIRS PTF and suggest that our PTF can predict with higher accuracy the Si content.

To better figure out the accuracy of our PTF, we plotted in Figure S1, the predicted versus measured $\mathrm{Si}_{\text {tot }}$ for only one iteration of the cross-validation step. In this figure, the predicted versus measured $\mathrm{Si}_{\text {tot }}$ distribution closely follow the one to one line with a smaller prediction uncertainty than the analytical uncertainty. Those results allow us considering that the predictions of this function are as good as Si measurements since the prediction uncertainties are within the range of analytical values. However, as explained by Landre et al. (2018), the analytical uncertainty was not taken into account in the prediction uncertainty calculation, as they were not always available. Despite this, the obtained PTF shows exceptional accuracy that is rarely obtained in environmental fields for PTFs (Minasny et al., 2009; Viscarra Rossel et al., 2006) (see Landre et al. (2018) for more information). 


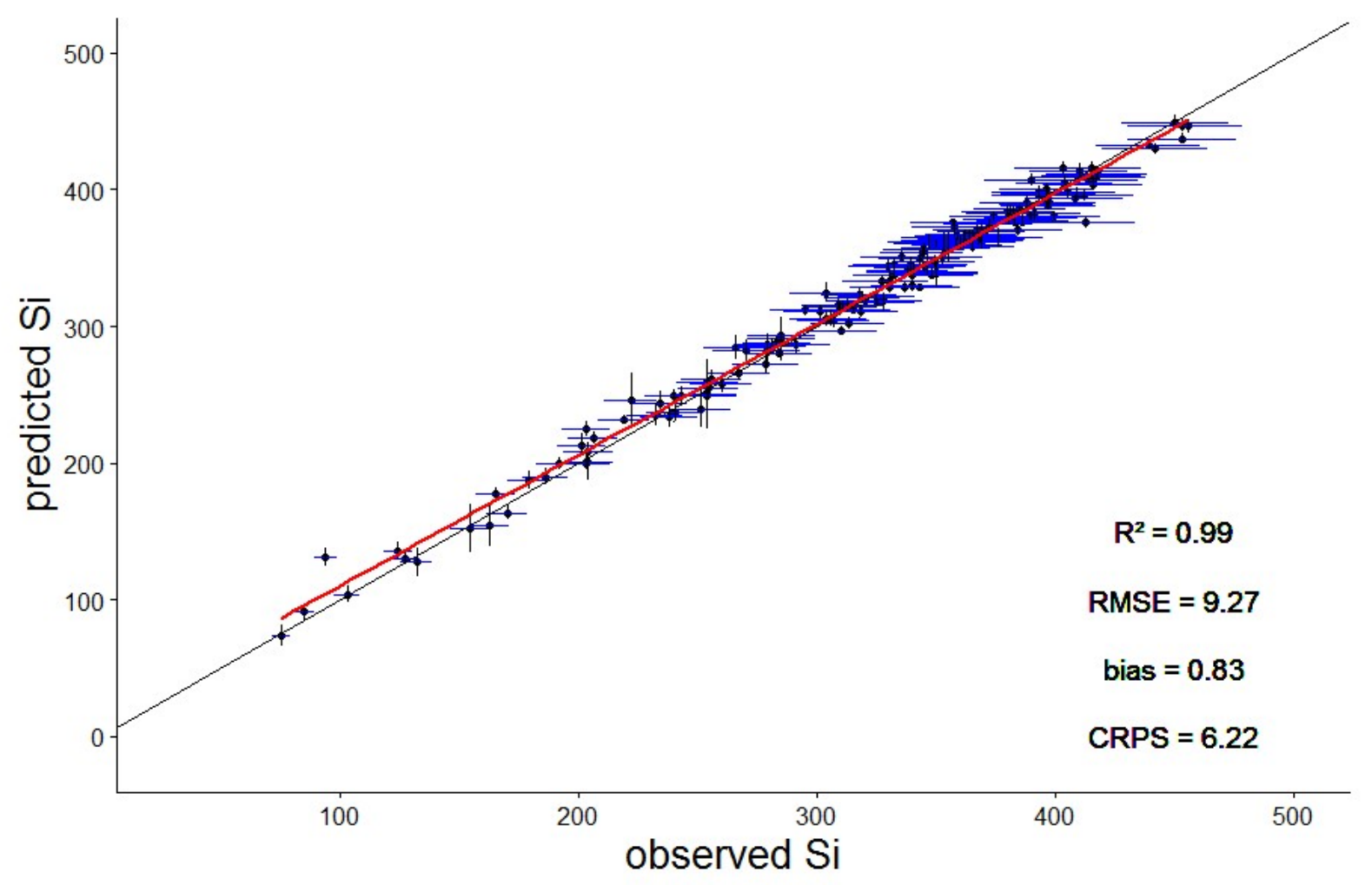

Figure S1: Predicted versus measured Si concentrations (in $\mathrm{g} \mathrm{kg}^{-1}$ ) for the first cross-validation replication of our Si concentration predictive function. In black, the one to one line and in red, the regression line. Black vertical error bars represent the prediction's uncertainty and blue horizontal error bars represent the analytical uncertainty. 


\section{DSM model validation}

The model performance was estimated using a cross validation. four conventional performance indicators were computed: the coefficient of determination $\left(\mathrm{R}^{2}\right)$, the mean square error (MSE), the root mean square error (RMSE, also known as standard error of prediction, SEP) and the bias, which is the mean residual of the model. In addition, a fifties indicator was calculated, the concordance which is a normalized statistic that determines the relative magnitude of the residual variance compared to the measured data variance (Moriasi et al., 2007; Nash and Sutcliffe, 1970). The results of the cross validation of the SCORPAN model are in accordance with previous digital soil mapping exercise of topsoil properties (Mulder et al., 2016). We found an $\mathrm{R}^{2}$ of 0.45, a MSE of 3647.99, a RMSE of $60.4 \mathrm{~g}$ $\mathrm{kg}^{-1}$, an important bias of 4.70 and a high concordance of 0.59 . 